\title{
GENOTOXIC EFFECTS OF GREEN TEA EXTRACT ON HUMAN LARYNGEAL CARCINOMA CELLS IN VITRO
}

\author{
Ksenija DURGO ${ }^{1}$, Sandra KOSTIĆ ${ }^{1}$, Katarina GRADIŠKI ${ }^{1}$, Draženka KOMES ${ }^{1}$, Maja OSMAK², \\ and Jasna FRANEKIĆ ${ }^{1}$
}

Faculty of Food Technology and Biotechnology ${ }^{l}$, Ruđer Bošković Institute², Zagreb, Croatia

Received in April 2011

CrossChecked in May 2011

Accepted in May 2011

\begin{abstract}
Green tea (Camellia sinensis) contains several bioactive compounds which protect the cell and prevent tumour development. Phytochemicals in green tea extract (mostly flavonoids) scavenge free radicals, but also induce pro-oxidative reactions in the cell. In this study, we evaluated the potential cytotoxic and prooxidative effects of green tea extract and its two main flavonoid constituents epigallocatechin gallate (EGCG) and epicatechin gallate (ECG) on human laryngeal carcinoma cell line (HEp2) and its crossresistant cell line CK2. The aim was to see if the extract and its two flavonoids could increase the sensitivity of the cisplatin-resistant cell line CK2 in comparison to the parental cell line. The results show that EGCG and green tea extract increased the DNA damage in the CK2 cell line during short exposure. The cytotoxicity of EGCG and ECG increased with the time of incubation. Green tea extract induced lipid peroxidation in the CK2 cell line. The pro-oxidant effect of green tea was determined at concentrations higher than those found in traditionally prepared green tea infusions.
\end{abstract}

KEY WORDS: cell line, cytotoxicity, DNA damage, epicatechin gallate, epigallocatechin gallate, green tea, glutathione, lipid peroxidation

A wide range of compounds naturally present in food scavenge free radicals, inhibit mutagen uptake or mutagenic biotransformation, activate or modulate cellular detoxifying mechanisms, and protect DNA from nucleophilic attack (1-3). Green tea is a rich source of flavonoids, secondary plant metabolites with similar chemical structure. They are characterised by condensed aromatic rings, which give specific colour, taste, and smell to these compounds (2-4) and are involved in defence against predators and microorganisms or act as repellents as well (5). In plant cells, different redox reactions generate free radicals and reactive oxygen species (ROS). Flavonoids effectively inactivate ROS in an early phase of development. They also decrease or increase the activity of enzymes and cell receptors and can interfere with basic cellular biochemical pathways. Under certain conditions, flavonoids can induce prooxidative events, which result in cell death (5-8). Even though we know a lot about their biological activity, there is still much to learn about structural requirements and mechanisms responsible for effects they produce. Earlier studies (1-7) suggest that polyphenol constituents from green tea suppress cancer growth in the oesophagus, stomach, colon, liver, pancreas, skin, breast, lung, bladder, and prostate.

In this study, we used human laryngeal carcinoma cell line HEp2 and its drug-resistant CK2 subline in order to determine their susceptibility to green tea extract and to its two main flavonoid constituents 
epigallocatechin gallate (EGCG) and epicatechin gallate (ECG), administered as separate compounds. We studied cytotoxicity, lipid peroxidation, and the level of primary DNA damage in both cell types.

\section{MATERIALS AND METHODS}

\section{Chemicals and reagents}

3 - (4,5 - di me thylthi azo $1-2$ - y 1$)-2,5$ diphenyltetrazolium bromide(MTT), malondyaldehyde (MDA), NADH, sodium-pyruvate, thiobarbituric acid (TBA), EGCG, ECG, and other chemicals were obtained from Sigma Chemical Co. (St. Louis, USA), unless specified otherwise.

Dried green tea leaves were purchased at a local herbal store. To obtain the extract we poured $200 \mathrm{~mL}$ of $10 \%$ ethanol solution over $2 \mathrm{~g}$ leaf samples at room temperature and left them to infuse for five minutes. The extract was then evaporated to dryness and redissolved in DMSO. In all experiments, the final concentration of DMSO was below $0.1 \%$. Different concentrations of catechins and green tea extract were prepared in a Dulbecco's modified Eagle's medium (DMEM). Extract concentration obtained after pouring a $200 \mathrm{~mL}$ of hot water over $2 \mathrm{~g}$ leaf sample was considered $1 \mathrm{x}$ concentration. All dilutions were prepared in DMEM. As proposed in literature (11), we tested them for the formation of microscopically visible crystals to ensure that all components were soluble in DMEM.

\section{Human cell lines}

Human laryngeal carcinoma cell line HEp2 and its cross-resistant subline CK2 were grown as monolayer cultures in DMEM supplemented with $10 \%$ of foetal bovine serum, 4,500 $\mathrm{mg} \mathrm{L}^{-1}$ glucose, pyridoxine, and $1 \%$ penicillin/streptomycin solution. The CK2 subline was developed in the Laboratory for Genotoxic Agents at Ruđer Bošković Institute, Zagreb, Croatia, by treating parental HEp2 cells with stepwise-increasing concentrations of cisplatin (12). The treated CK2 cells developed resistance to cisplatin and cross-resistance to vincristine, methotrexate, fluorouracil, mitomycin $\mathrm{C}$, and carboplatin $(12,13)$. This cross-resistance was accompanied with sensitivity to amphotericin B (13), greater hyperthermia-reduced intracellular cisplatin accumulation, increased levels of markers for invasion and metastasis, cathepsin $\mathrm{D}$, and urokinase plasminogen activator, and increased expression of integrins (14).
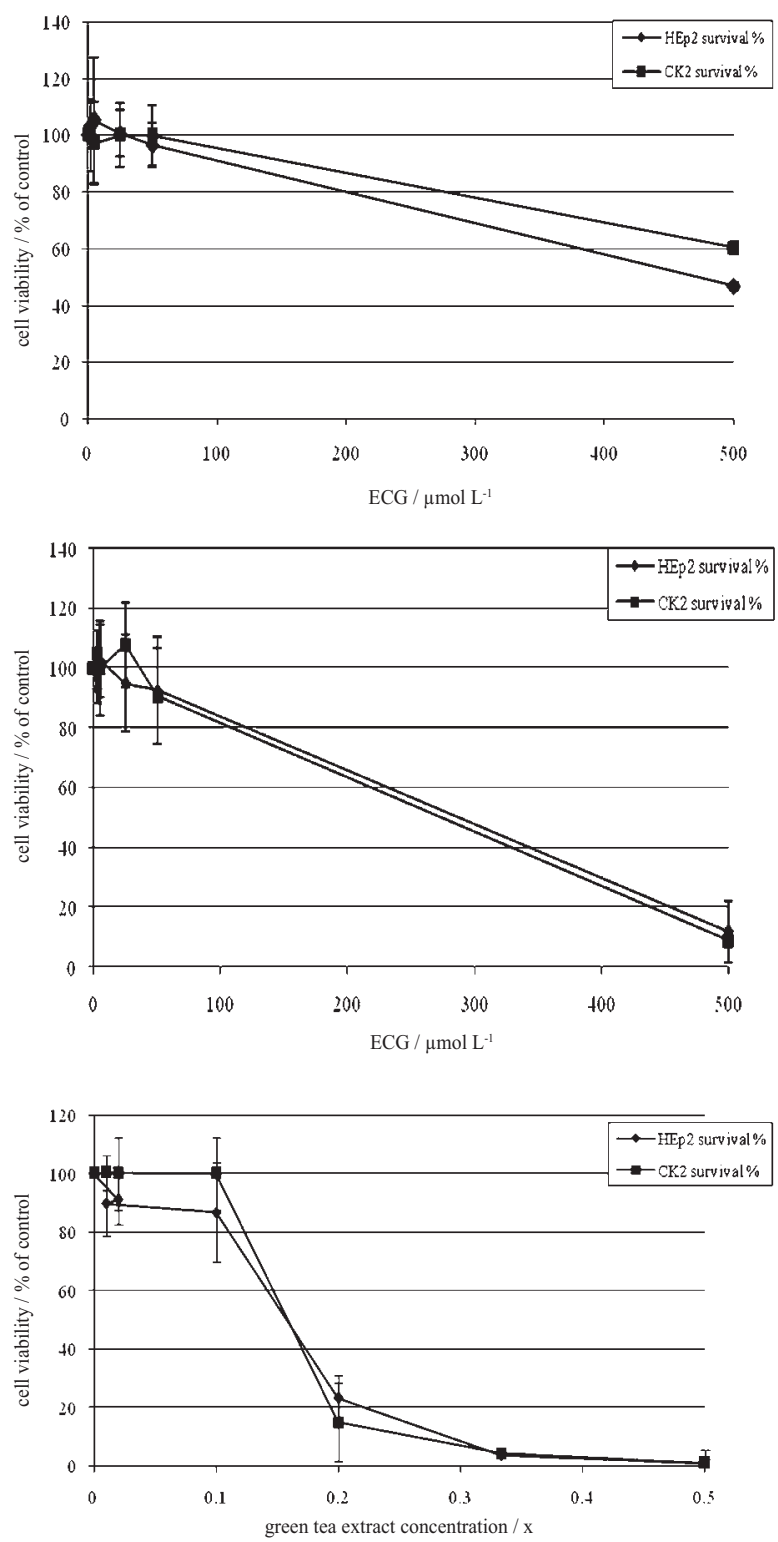

Figure 1 Survival of human laryngeal carcinoma cells HEp2 and CK2 following 48-h treatment with catechins and green tea extract. Results are shown as mean values $\pm S D$ of three experiments. The estimated half maximal effective concentration $\left(E C_{50}\right)$ in parental HEp 2 cells was $473.21 \mu_{m o l ~ L^{-1}}$ for $E C G$, $283.8 \mu \mathrm{mol} \mathrm{L} \mathrm{L}^{-1}$ for EGCG, and $0.176 x$ (with respect to the basic concentration) for green tea extract. In the CK2 subline $E C_{50}$ was $284.7 \mu \mathrm{mol} \mathrm{L} \mathrm{L}^{-1}$ for $E G C G$ and $0.185 x$ for green tea extract. ECG did not cause death to $50 \%$ of cells in the investigated range of concentrations.

\section{Cytotoxicity assay}

HEp2 and CK2 cells were seeded in 96-well plates in the concentration of $6 \times 10^{3}$ cells per 180 microlitres per well. The next day, cells were treated with a range of concentrations of either catechin $\left(2.5 \mu \mathrm{mol} \mathrm{L}^{-1}\right.$ to 



Figure 2 Survival of human laryngeal carcinoma cells HEp2 and CK2 following 72-h treatment with catechins and green tea extract. Results are shown as mean values $\pm S D$ of three experiments. The estimated half maximal effective concentration $\left(E C_{50}\right)$ in parental HEp 2 cells was $359.2 \mu_{\text {mol L }}{ }^{-1}$ for ECG, $301.7 \mu \mathrm{mol} \mathrm{L} L^{-1}$ for EGCG, and $0.19 x$ (with respect to the basic concentration) for green tea extract. In the CK2 subline $E C_{50}$ was $359.2 \mu \mathrm{mol} \mathrm{L} L^{-1}$ for $E C G$, $255.5 \mu \mathrm{mol} L^{-1}$ for $E G C G$, and $0.178 x$ for green tea extract.

$500 \mu \mathrm{mol} \mathrm{L}-1)$ and green tea extract $(0.02 \mathrm{x}$ to $0.5 \mathrm{x})$. In the latter case, $0.02 \mathrm{x}$ corresponds to a concentration 50 times lower than the original extract concentration. After 48 and 72 hours (period of early and late exponential phase), DMEM was removed, and cells incubated with a $10 \%$ MTT solution $(15,16)$. Viable cells have active mitochondrial dehydrogenase enzymes which metabolise yellow-coloured tetrazolium salt into a blue formazan. Absorbance was read at $540 \mathrm{~nm}$ on a Cecil microplate spectrophotometer (Cecil Instruments Ltd., Technical Centre Cambridge, UK). Each experiment was repeated three times.

\section{Measurement of lipid peroxidation}

Briefly, $13.5 \mathrm{~mL}$ of cell suspension $\left(4.5 \times 10^{5}\right.$ cells $)$ was seeded in $10-\mathrm{cm}$ Petri dishes. After attachment, the cells were incubated with the highest nontoxic concentration of the examined catechins and green tea extract for $48 \mathrm{~h}$ and $72 \mathrm{~h}$. Positive control cells were exposed to $10 \mu \mathrm{mol} \mathrm{L}^{-1}$ hydrogen peroxide for $30 \mathrm{~min}$ to induce oxidative stress. After incubation the cells were scraped, washed, and lysed in potassium chloride $(1.15 \%)$ for $30 \mathrm{~min}$. The mixture was centrifuged and cell supernatant incubated with trichloroacetic acid (TCA; $100 \mathrm{~g} \mathrm{~L}^{-1}$ ) at $100{ }^{\circ} \mathrm{C}$ for $15 \mathrm{~min}$. The mixture was then cooled with tap water, centrifuged at $1000 \mathrm{rpm}$ for another $10 \mathrm{~min}$, mixed with thiobarbituric acid (TBA; $0.8 \%$ ), and incubated again at $100{ }^{\circ} \mathrm{C}$ for 15 min. After cooling with tap water, the absorbance of the samples was read at $532 \mathrm{~nm}$ and then at $600 \mathrm{~nm}$ (value of nonspecific absorbance). The concentration of malondyaldehyde-thiobarbituric acid (MDA-TBA) complex was calculated from the standard curve (17, 18). Concentration of cellular proteins was estimated using the Bradford method (19). Each experiment was repeated three times.

\section{Alkaline comet assay}

The comet assay followed the procedure described by Singh et al. (20), with some modifications. We prepared three replicate slides per sample of treated cells as described in detail by Rusak et al. (21). The slides were immersed in freshly prepared ice-cold alkaline lysis solution $\left(2.5 \mathrm{~mol} \mathrm{~L}^{-1} \mathrm{NaCl}, 100 \mathrm{mmol}\right.$ $\mathrm{L}^{-1} \mathrm{Na}_{2}$ EDTA, $10 \mathrm{mmol} \mathrm{L}^{-1}$ Tris-HCl, $1 \% \mathrm{Na}-$ sarcosinate, $\mathrm{pH} 10$ ) with $1 \%$ Triton $\mathrm{X}-100$ and $10 \%$ dimethyl sulfoxide (Kemika, Zagreb, Croatia) for one hour. Alkaline denaturation (20 min) and electrophoresis $(20 \mathrm{~min}$ at $25 \mathrm{~V}$ ) were carried out in a freshly prepared buffer (300 mmol L-1 $\mathrm{NaOH}, 1$ mmol L-1 $\mathrm{Na}_{2}$ EDTA, $\mathrm{pH}$ 13.0) at $4{ }^{\circ} \mathrm{C}$. After electrophoresis, the slides were neutralised with $0.4 \mathrm{~mol} \mathrm{~L}^{-1}$ Tris-HCl buffer (pH 7.5), stained with ethidium bromide $\left(20 \mu \mathrm{g} \mathrm{mL}^{-1}\right)$, and analysed using a 250x epifluorescence microscope (Leitz, Germany) and the Comet Assay II image analysis system (Perceptive Instruments Ltd., Suffolk, UK). To measure DNA damage we selected tail DNA \% as a reliable parameter. A total of 150 comets 
per sample (50 from each replicate slide) were scored and data pooled.

\section{Statistical analyses}

For statistical analysis we used commercial software SPSS version 8.0 (SPSS Inc., Chicago, IL, USA). We calculated the standard parameters of descriptive statistics. Inter-group comparisons were performed using the one-way analysis of variance (ANOVA) with post-hoc Dunnett's test. The probability level of $\mathrm{P}<0.05$ was considered significant.

\section{RESULTS}

\section{Cytotoxicity of ECG, EGCG, and green tea extract}

The MTT test (Figures 1 and 2) and morphological analysis of treated cells showed that ECG and EGCG were not toxic in the concentration range from $2.5 \mu \mathrm{mol} \mathrm{L}{ }^{-1}$ to $50 \mu \mathrm{mol} \mathrm{L}^{-1}$. The highest concentration of ECG $\left(500 \mu \mathrm{mol} \mathrm{L}^{-1}\right)$ caused a similar toxic effect on both cell lines and cytotoxicity of this compound increased in the late exponential phase. Even more cytotoxic in both cell lines at this concentration was EGCG, as measured in the early exponential phase after $48 \mathrm{~h}$ of incubation. ECG and EGCG concentrations in cells exposed to green tea extract were $62.4 \mu \mathrm{mol}$ $\mathrm{L}^{-1}$ and $283.6 \mu \mathrm{mol} \mathrm{L}^{-1}$, respectively. Even so, green tea extract had a significant toxic effect on both cell lines at either exponential phase, which increased with the time of incubation. In other words, it showed higher cytotoxic potential even at concentrations five times lower than in a regular cup of green tea $($ concentration $=\mathrm{x})$.

\section{Lipid peroxidation}

After $72 \mathrm{~h}$ of incubation, green tea extract at $0.1 \mathrm{x}$ concentration caused lipid peroxidation in both cell lines. EGCG $\left(50 \mu \mathrm{mol} \mathrm{L}^{-1}\right)$ decreased the basal level of lipid peroxidation in the resistant subline CK2. The two cell lines however did not significantly differ in basal lipid peroxidation (Figure 3 ).

\section{Comet assay}

Forty-eight-hour incubation of HEp2 cells with green tea extract did not induce significant primary DNA damage in comparison to control, but $72-\mathrm{h}$ incubation did (Table 1). In contrast, 48-h incubation
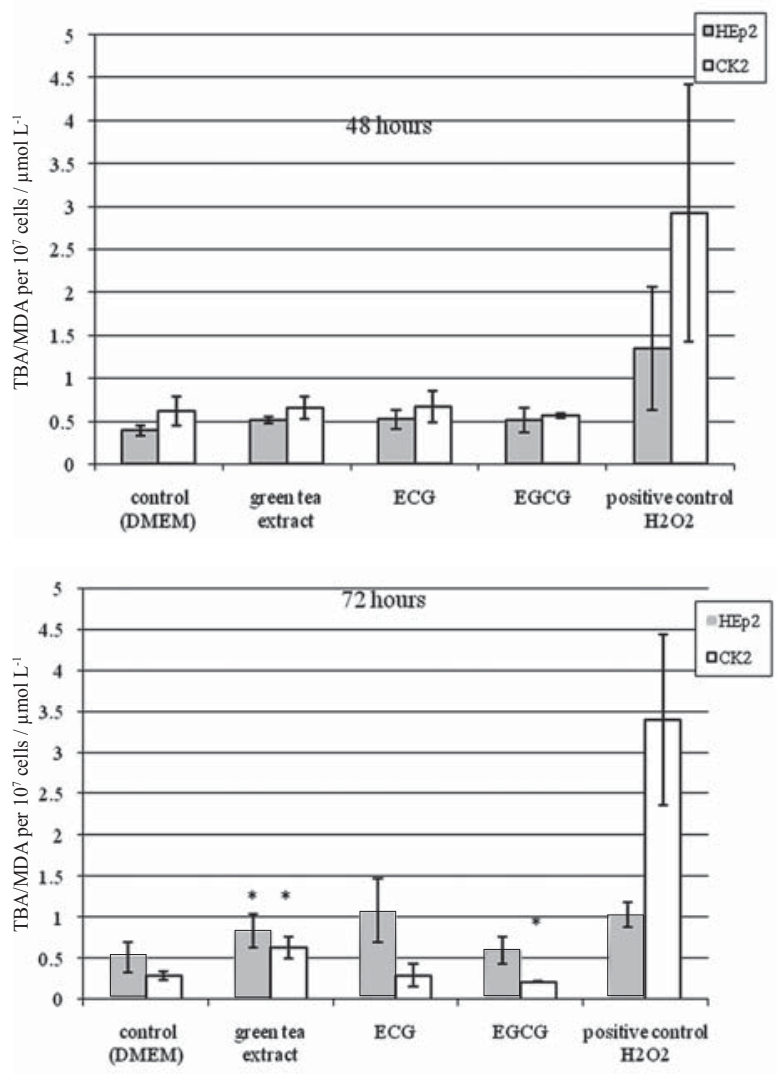

Figure 3 Concentration of TBA-MDA complex in HEp2 and CK2 cells after the 48-h and 72-h treatment with catechins $\left(50 \mu \mathrm{mol} \mathrm{L} L^{-1}\right)$ and green tea extract $(0.1 x)$. The results represent mean values $\pm S D$ of three experiments.

* statistically significant difference vs. control $(P<0.05)$.

of HEp2 cells with ECG or EGCG decreased tail DNA $\%$ in comparison to control, but it increased with incubation time to values similar to control (Table $1)$.

The cross-resistant subline CK2 showed no changes in tail DNA \% whether exposed to green tea extract or either of the catechins and regardless of incubation time (Table 2).

\section{DISCUSSION}

\section{Cytotoxic effect of catechins and green tea extract}

Existing literature data indicate that catechins possess antioxidant, prooxidant, antitumour, or cytotoxic properties, usually in the concentrations ranging from $10 \mu \mathrm{mol} \mathrm{L}^{-1}$ to $1,000 \mu \mathrm{mol} \mathrm{L}^{-1}$ (22). Although these concentrations are not likely to be found in the organism of individuals who consume 
Table 1 Alkaline comet assay findings in HEp2 cells after $48 \mathrm{~h}$ and $72 \mathrm{~h}$ of incubation with green tea extract and catechins

\begin{tabular}{|c|c|c|c|c|c|c|}
\hline \multirow{4}{*}{ Sample } & \multicolumn{6}{|c|}{ HEp2 cell line } \\
\hline & \multicolumn{6}{|c|}{ Tail intensity / \% DNA } \\
\hline & \multicolumn{3}{|c|}{$48 \mathrm{~h}$} & \multicolumn{3}{|c|}{$72 \mathrm{~h}$} \\
\hline & Mean \pm S.D & Median & Range & Mean \pm S.D & Median & Range \\
\hline Green tea extract $(0.1 \mathrm{x})$ & $3.17 \pm 0.71$ & 1.08 & 0 to 40.44 & $9.55 \pm 1.03^{* *}$ & 1.8 & 0 to 68.23 \\
\hline $\mathrm{ECG}\left(50 \mu \mathrm{mol} \mathrm{L}^{-1}\right)$ & $2.34 \pm 0.65^{*}$ & 0.92 & 0 to 32.03 & $4.63 \pm 0.83$ & 1.26 & 0 to 31.02 \\
\hline EGCG $\left(50 \mu \mathrm{mol} \mathrm{L}^{-1}\right)$ & $2.19 \pm 0.65^{*}$ & 0.78 & 0 to 39.91 & $5.82 \pm 0.88$ & 1.47 & 0to 53.27 \\
\hline $\mathrm{NC}$ & $5.18 \pm 0.86$ & 1.22 & 0 to 54.69 & $4.12 \pm 0.80$ & 1.14 & 0 to 37.59 \\
\hline
\end{tabular}

$S D$ - standard deviation; ECG-epicatechin gallate; EGCG-epigallocatechin gallate; $N C$ - negative control

150 comets per compound were measured. Inter-group comparisons were performed using ANOVA with Dunnett's post-hoc test.

* significantly different $(P<0.05)$ from negative control

** significantly different from the other groups

green tea or green tea extract, it would be useful to determine potential benefits and side effects of highdose catechin supplementation. In our study, the cytotoxicity of ECG/EGCG and green tea extract increased with concentration and time of incubation. The cytotoxic effect of green tea extract was greater than of either of the catechins. This is in accordance with results reported by other investigators (23) and can be explained by the synergistic effect of toxic compounds in green tea. EGCG and green tea extract were more toxic for the cross-resistant CK2 subline in the first few hours of incubation (data not shown), but this effect ebbed after prolonged exposure of CK2 cells to green tea extract (Figure 1 and Figure 2). At nanomolar concentrations, catechins are rapidly biotransformed by methylation, sulphation, and ringfission reactions to eventually yield phenylacetic and phenylpropionic acids (24). Reactive oxygen species are formed during cellular metabolism of higher concentrations of catechins and are often responsible for their cytotoxic effects in tumour cell lines (25). Yamamoto et al. (25) proved that high concentrations of green tea catechins did not induce ROS formation in normal keratinocytes and that their ROS level continuously decreased. Contrary to those findings, the same group (25) detected continuous ROS formation in oral carcinoma cell lines, suggesting that catechins could both induce ROS and scavenge free radicals, depending on the cell type. Yamamoto et al. (25) have suggested that carcinoma cells are more susceptible to the cytotoxic effect of catechins and green tea extract than cell lines derived from healthy cells, judging by apoptotic events. They have also found that response differs between cell types, depending on their ability to tolerate polyphenols. Cells in frequent contact with catechins can tolerate them in higher concentrations. According to Yamamoto et al. (25), increased cell sensitivity to these compounds is evidenced by its inability to differentiate. Yang et al. (26) have proposed another mechanism responsible

Table 2 Alkaline comet assay findings in CK2 cells after 48 and 72 hours of incubation with green tea extract and catechins

\begin{tabular}{|c|c|c|c|c|c|c|}
\hline \multirow{4}{*}{ Sample } & \multicolumn{6}{|c|}{ CK2 cell line } \\
\hline & \multicolumn{6}{|c|}{ Tail intensity / \% DNA } \\
\hline & \multicolumn{3}{|c|}{$48 \mathrm{~h}$} & \multicolumn{3}{|c|}{$72 \mathrm{~h}$} \\
\hline & $\begin{array}{c}\text { Mean } \\
\pm \text { S.D }\end{array}$ & Median & Range & Mean \pm S.D & Median & Range \\
\hline Green tea extract $(0.1 \mathrm{x})$ & $3.48 \pm 0.77$ & 0.92 & 0 to 57.42 & $6.49 \pm 1.00$ & 1.1 & 0 to 60.32 \\
\hline $\mathrm{ECG}\left(50 \mu \mathrm{mol} \mathrm{L}{ }^{-1}\right)$ & $3.78 \pm 0.79$ & 1.02 & 0 to 34.94 & $4,13 \pm 0.81$ & 1.1 & 0 to 55.08 \\
\hline EGCG $\left(50 \mu \mathrm{mol} \mathrm{L}^{-1}\right)$ & $4.58 \pm 0.83$ & 1.17 & 0 to 42.15 & $4,52 \pm 0.83$ & 1.18 & 0 to 30.01 \\
\hline $\mathrm{NC}$ & $3.92 \pm 0.91$ & 1.1 & 0 to 61.56 & $3,05 \pm 0.73$ & 0.96 & 0 to 53.13 \\
\hline
\end{tabular}

$S D$ - standard deviation; ECG - epicatechin gallate; EGCG-epigallocatechin gallate; $N C$ - negative control 150 comets per compound were measured. Inter group comparisons were performed using ANOVA with Dunnett's post-hoc test. No significant differences $(P<0.05)$ were found between the groups. 
for catechin toxic effects; EGCG inhibits telomerase activity causing apoptotic events in the exposed cells. Naasani et al. (27) observed a similar effect for ECG, as it inhibited telomerase activity by causing G1 arrest.

\section{Lipid peroxidation}

Prooxidative and antioxidative properties of bioactive compounds, including green tea extract and ECG/EGCG, are determined by measuring MDA, which is a product of fatty acid degradation caused by free radicals (28). Increased lipid peroxidation after treatment with green tea extract was detected in both cell lines after $72 \mathrm{~h}$ of incubation. The finding that EGCG decreased the control level of lipid peroxidation in the cross-resistant subline indicates its antioxidative nature. ECG did not show any effect (Figure 3). The antioxidative effect of EGCG in comparison to ECG can be explained by the additional -OH group on 5' position of the EGCG molecule (21). Elbling et al. (29) showed that green tea extract and EGCG in concentrations ranging from $10 \mu \mathrm{mol} \mathrm{L}^{-1}$ to $20 \mu \mathrm{mol}$ $\mathrm{L}^{-1}$ induced oxidative stress and DNA damage in HL60 cells. However, the levels of EGCG that can be found in systemic circulation are measured in nanomolar concentrations, while most studies are based on micromolar or milimolar concentrations, which seem to produce prooxidative effects of EGCG and eventually oxidative stress, DNA degradation, lipid peroxidation, and $\mathrm{H}_{2} \mathrm{O}_{2}$ production (28). Lower concentrations and shorter time of exposure in turn produce antioxidative effects of EGCG. It is possible that EGCG in nanomolar concentrations causes hydrogen peroxide production in physiological concentrations, which mediates cell signalling pathways, proliferation, and differentiation (30). A study in humans by Kimura et al. (31) revealed that ingestion of a single (164 mg) and a double (328 mg) catechin dose in green tea did not change its antioxidant activity because they were conjugated or methylated after absorption by the digestive system. However, antioxidant activity in cells decreased significantly seven days after tea catechin consumption stopped (31).

\section{Comet assay}

Our results show that green tea extract causes DNA damage. Its genotoxic effect increased with the time of exposure (Table 1). DNA damage was more pronounced in the parental HEp2 cell line than in the resistant CK2 subline. We suppose that the HEp2 cell line has a more susceptible genome. It is also possible that the CK2 cell line developed more effective endogenous repair mechanisms. A case in point is that DNA damage in the CK2 subline caused by catechins in the first 48 hours withdrew as incubation continued (Table 2).

At 48 hours, both EGCG and ECG protected the HEp2 cells (Table 1). Similarly, Kanadzu et al. (32) found that EGCG in concentrations ranging from $0.01 \mu \mathrm{mol} \mathrm{L}^{-1}$ to $10 \mu \mathrm{mol} \mathrm{L}^{-1}$ lowered DNA breakages in human lymphocytes, but also showed a strong genotoxic effect at higher concentrations $(1 \mathrm{mmol}$ $\left.\mathrm{L}^{-1}\right)(32)$.

Green tea extract and catechins in green tea extract cause both antioxidative and prooxidative effects, depending on the cell type, time of exposure, and concentration. An insight into the exact mechanism of genotoxic or protective action would help a lot to devise successful application of these compounds in human population. Our findings indicate that high concentrations of catechins and other biologically active compounds can cause serious and unexpected side effects.

Even so, biologically active compounds in concentrations present in green tea extract can have a significant toxic effect on cells resistant to a range of cytostatics. This suggests that consumption of green tea could help in cancer prevention. Because of its inhibitory effect on laryngeal cell growth, green tea should take place in everyday diet. However, as green tea is a complex mixture of several biologically active constituents, future investigations should further clarify their apoptotic and anticancer potential.

\section{Acknowledgements}

This study was supported by the Ministry of Science, Education and Sports grant to projects no. 058-0000000-3470 and 058-0582261-2246. The authors wish to thank the Mutagenesis Unit at the Institute for Medical Research and Occupational Health (Zagreb, Croatia) for allowing free access to fluorescence microscope and image analysis software.

\section{REFERENCES}

1. Dixon RA, Steel CL. Flavonoids and isoflavonoids-a gold mine for metabolic engeenering. Trends Plant Sci 1999;4:394400 . 
2. De Flora S, Izzotti A, D’Agostini F, Balansky RM, Noonan $\mathrm{D}$, Albini A. Multiple points of intervention in the prevention of cancer and other mutation-related diseases. Mutat Res 2001;480-481:9-22.

3. Decker EA. Phenolics: prooxidants or antioxidants? Nutr Rev 1997;55:396-8.

4. Pietta PG. Flavonoids as antioxidants. J Nat Prod 2000;63:1035-42.

5. Aherne SA, O'Brien NM. Dietary flavonols: chemistry, food content and metabolism. Nutrition 2002;18:75-81.

6. Breinholt V. Desirable versus harmful levels of intake of flavonoids and phenolic acids. In: Kumpulainen JT, Salonen JT, editors. Natural antioxidants and anticancerogens in nutrition, health and disease. London: The Royal Society of Chemistry; 1999. p. 100-10.

7. Roderick HD. Frontiers in polyphenols and cancer prevention. J Nutr 2007;137(Suppl 1):267S-9S.

8. Chen D, Ping Dou Q. Tea polyphenols and their roles in cancer prevention and chemotherapy. Int J Mol Sci 2008;9:1196-206.

9. Rusak G, Gutzeit HO, Müller JL. Effects of structurally related flavonoids on hsp gene expression in human promyeloid leukaemia cells. Food Technol Biotechnol 2002;40:267-73.

10. Reiners JJ Jr, Clift R, Mathieu P. Suppresion of cell cycle progression by flavonoids; dependence on aryl hydrocarbon receptor. Carcinogenesis 1999;20:1561-6.

11. Plochmann K, Korte G, Koutsilieri E, Richling E, Riederer P, Rethwilm A, Schreier P, Scheller C. Structure-activity relationships of flavonoid-induced cytotoxicity on human leukemia cells. Arch Biochem Biophys 2007;460:1-9.

12. Osmak M, Nikšić D, Brozović A, Ambriović Ristov A, Vrhovec I, Škrk J. Drug resistant tumor cells have increased levels of tumor markers for invasion and metastasis. Anticancer Res 1999;19:3193-8.

13. Brozović A, Fritz G, Christmann M, Zisowsky J, Jaehde U, Osmak M, Kaina B. Long-term activation of SAPK/JNK, p38 kinase and fas-L expression by cisplatin is attenuated in human carcinoma cells that aquired drug resistance. Int J Cancer 2004;112:974-85.

14. Brozović A, Šimaga Š Osmak M. Induction of heat shock protein 70 in drug-resistant cells by anticancer drugs and hyperthermia. Neoplasma 2001;48:99-103.

15. Čemažar M, Marolt D, Lavrič M, Serša G. Comparison of colorimetric MTT and clonogenic assays for irradiation and cisplatin treatment on murine fibrosarcoma SA-1 cells. Radiol Oncol 1999;33:303-8.

16. Matsuo M, Sasaki N, Saga K, Kaneko T. Cytotoxicty of flavonoids toward cultured normal human cells. Biol Pharm Bull 2005;28:253-9.

17. Cereser C, Boget S, Parvaz P, Revol A. Thiram-induced cytotoxicity is accompanied by a rapid and drastic oxidation of reduced glutathione with consecutive lipid peroxidation and cell death. Toxicology 2001;163:153-62.

18. McCarthy S, Somayajulu M, Sikorska M, Borowy-Borowski $\mathrm{H}$, Pandey S. Paraquat induces oxidative stress and neuronal cell death; neuroprotection by water soluble Coenzyme Q-10. Toxicol Appl Pharmacol 2004;201:21-31.

19. Bradford MM. A rapid and sensitive method for the quantification of microgram quantities of protein utilising the principle of protein-dye binding. Anal Biochem 1976;72:248-54.

20. Singh NP, McCoy MT, Tice RR, Schneider EL. A simple technique for quantitation of low levels of DNA damage in individual cells. Exp Cell Res 1988;175:184-91.

21. Rusak G, Piantanida I, Mašić L, Kapuralin K, Durgo K, Kopjar N. Spectrophotometric analysis of flavonoid-DNA interactions and DNA damaging/protecting and cytotoxic potential of flavonoids in human peripheral blood lymphocytes. Chem-Biolo Interact 2010;188:181-9.

22. Guo Q, Zhao B, Shen S, Hou J, Hu J, Xin W. ESR study on the structure-antioxidant activity relationship of tea catechins and their epimers. BBA - General Subjects 1999;1427:1323.

23. Babich H, Krupka ME, Nissim HA, Zuckerbraun HL. Differential in vitro cytotoxicity of (-)-epicatechin gallate (ECG) to cancer cells from the human oral cavity. Toxicol in Vitro 2005;19:231-42.

24. Khan N, Mukhtar H. Tea polyphenols for health promotion. Life Sci 2007;81:519-33.

25. Yamamoto T, Hsu S, Lewis J, Wataha J, Dickinson D, Singh B, Bollag WB, Lockwood P, Ueta E, Osaki T, Schuster G. Green tea polyphenol causes differential oxidative environments in tumor versus normal epithelial cells. J Pharmacol Exp Therap 2003;307:230-6.

26. Yang GY, Liao J, Kim K, Yurkow EJ, Yang CS. Inhibition of growth and induction of apoptosis in human cancer cell lines by tea polyphenols. Carcinogenesis 1998;4:611-6.

27. Naasani I, Seimiya H, Tsuruo T. Telomerase inhibition, telomere shortening, and senescence of cancer cells by tea catechins. Biochem Biophys Res Commun 1998;240:3916 .

28. Morrow J. Looking for lipid peroxidation in vitro and in vivo: is seeing believing? [displayed on 19 May 2011]. Available at http://www.sfrbm.org/frs/Morrow2002.pdf.

29. Elbling L, Weiss RM, Teufelhofer O, Uhl M, Knasmueller S, Schulte-Herman R, Berger W, Micksche M. Green tea extract and (-)-epigallocatechin-3-gallate, the major tea catechin, exert oxidant but lack antioxidant activities. FASEB J 2005; 19:807-9.

30. Forman HJ, Fukuto JM, Torres M. Redox signalling: thiol chemistry defines which reactive oxygen and nitrogen species can act as second messengers. Am J Phisiol Cell Physiol 2004;287:C246-56.

31. Kimura M, Umegaki K, Kasuya K, Sugisawa A, Higuchi M. The relation between single/double or repeated tea catehin ingestions and plasma antioxidant activity in humans. Eur J Clin Nutr 2002;56:1186-93.

32. Kanadzu M, Lu Y, Morimoto K. Dual function of (-)epigallocatechin gallate (EGCG) in healthy human lymphocytes. Cancer Lett 2006;241:250-5. 


\section{Sažetak}

\section{GENOTOKSIČNI UČINAK EKSTRAKTA ZELENOG ČAJA NA LJUDSKE STANICE RAKA GRKLJANA U KULTURI}

Zeleni čaj, koji je vrlo popularno piće, proizvodi se iz biljke Camellia sinensis i bogat je flavonoidima za koje se smatra da imaju važnu ulogu u sprečavanju nastanka raka. Kao najvažniji mehanizmi djelovanja flavonoida najčešće se spominju vezanje slobodnih radikala te sprečavanje nastanka reaktivnih kisikovih skupina. Cilj ovog rada bio je istražiti potencijalni genotoksični učinak ekstrakta zelenog čaja te epigalokatehin galata (EGCG) i epikatehin galata (ECG), flavonoida koji se u zelenom čaju nalaze u najvišoj koncentraciji. Dobiveni su rezultati pokazali da EGCG i ekstrakt zelenog čaja izazivaju povećanu citotoksičnost otporne stanične linije raka grkljana CK2 nakon kraće inkubacije. Produljenjem vremena inkubacije povećava se citotoksičnost istraživanih spojeva. Također, ekstrakt zelenog čaja izaziva lipidnu peroksidaciju u CK2-stanicama. Prooksidativni učinak ekstrakta zelenog čaja u koncentracijama višim od onih prisutnih u infuzijskoj otopini dobivenoj tradicionalnim načinom, imaju prooksidativno djelovanje.

KLJUČNE RIJEČI: epigalokatehingalat, epikatehingalat, glutation, lipidna peroksidacija, oštećenja DNA, stanična linija, zeleni čaj

\section{CORRESPONDING AUTHOR:}

Ksenija Durgo, PhD

Laboratory for Biology and Microbial Genetics

Zagreb University Faculty of Food Technology and Biotechnology

Pierottijeva 6, Zagreb, Croatia

E-mail: kdurgo@pbf.hr 